\title{
Entre destruições, achados e invenção: a restauração da Sé de Olinda no âmbito do Programa Integrado de Reconstrução das Cidades Históricas do Nordeste
}

Renata Cabral ${ }^{1}$

RESUMO: Este artigo propõe-se a analisar ideias, agentes e instituições envolvidos no restauro da igreja matriz de S. Salvador, a Sé de Olinda, em Pernambuco, realizado entre 1974 e 1983, no âmbito do Programa Integrado de Reconstrução das Cidades Históricas do Nordeste (PCH). A igreja da Sé, edifício do século XVI, reconstruído após incêndio provocado pela invasão holandesa em Pernambuco no terceiro quartel do XVII, foi objeto de transformações ecléticas no começo do século $X X$, primeiramente ao gosto neogótico, e depois neobarroco, sendo esta última a feição que chegou aos anos do restauro. Na intervenção restauradora, optou-se por negar a obra como se apresentava à época, em um processo que envolveu destruições e "achados", a partir de prospecções e "invenções" reconstitutivas de possíveis formas do passado - um processo no qual teoria e prática de restauro, história da arquitetura e projeto compõem uma intricada rede.

PALAVRAS-CHAVE: Sé de Olinda. PCH. Restauro.

ABSTRACT: This article aims to analyse ideas, stakeholders and institutions involved on the Matriz de S. Salvador Church's restoration, better known as Sé de Olinda's Church, in Pernambuco state, between 1974 and 1983 as part of the Reconstructions of Northeast Historic Cities' Integrated Program (PCH). The XVI century Church was reconstructed after it was burned down during the Dutch invasion to the Pernambuco State on the XVII Century. During the XX century, the Sé de Olinda's Church went through important architectural interventions, initially taking neo gothic inspirations and later neo baroque. By the time of the $\mathrm{PCH}$ restoration, the face of the church was that of the neo baroque aesthetic. These two interventions were completely ignored during the 1974 restoration process as they were considered without architectural value and therefore not worth of conservation. The restoration process took into account archaeologic's findings, but also destroyed part of the fabric of the building and added new elements trying to bring the church to a possible XVI Century aesthetic. It was a process where theory and restoration practice, history and architecture design were part of an intrinsic net.

KEYWORDS: Sé de Olinda. PCH. Restoration.
1. Docente do Departamento de Arquitetura e Urbanismo da Universidade Federal de Pernambuco. E-mail: renatacabral@yahoo.com.br. 
2. Sobre a relação do $\mathrm{PCH}$ com a promoção da descentralização da política de preservação do patrimônio cultural no Brasil, ver Sandra Rafaela Magalhães Corrêa (2012, p. 213-221); Márcia Sant'Anna (1995, p. 165)

3. Sant'Anna observa que o "PCH revelou-se um programa de ação e repasse de recursos que não interferia ou exercia influência nas questões teóricas da preservação. Portanto, não chegou a dividir ou ameaçar o poder do IPHAN, que, ao contrário, viu reforçada sua posição de instância detentora do saber". Cf. Márcia Sant'Anna (1995, p. 163).

4. Segundo Corrêa, a Fundação do Patrimônio Histórico e Artístico de Pernambuco passou de seis para cento e dez funcionários em quatro anos (a partir de sua criação em 1973), e de um orçamento de Cr\$ 100 mil para Cr\$ 7 milhões. Ver Sandra Rafaela Magalhães Corrêa (2012, p. 217).

5. Cf. Annateresa Fabris (1987).

6. Ver alcunha em Lauro Cavalcanti (2000). Sobre o assunto, ver, ainda, Silvana Rubino (1996), Maria Cecília Londres Fonseca (1997) e José Pessoa (1999).

7. Cf. Geraldo Gomes da Silva (1987, p. 179).
A restauração da igreja matriz de S. Salvador, a Sé de Olinda, cujas obras foram executadas entre 1974 e 1983, teve como agente financiador o Programa Integrado de Reconstrução das Cidades Históricas do Nordeste (PCH) e como agente executor e elaborador do projeto a Fundação do Patrimônio Histórico e Artístico de Pernambuco (Fundarpe), criada em 1973². Seguindo a estrutura do programa, o lphan foi o órgão fiscalizador ${ }^{3}$.

Esse caso, a princípio mais um dos restauros a confirmar o perfil desenvolvimentista do programa, a ilustrar a história de uma fundação de âmbito estadual que amplia seu orçamento e seu quadro de funcionários de forma muito significativa ${ }^{4}$, nos possibilita ir além das questões estruturais por ele postas. A Igreja da Sé, construída no século XVI e reconstruída após incêndio holandês no terceiro quartel do século XVII, no século XX foi objeto de transformações, primeiramente ao gosto neogótico (década de 1910), e depois neobarroco (década de 1930), sendo esta última a feição que chegou aos anos do restauro. Na intervenção restauradora optou-se por negar essas duas reformas como tendo valor a ser conservado. Uma primeira aproximação às escolhas envolvidas no restauro, assim como às repercussões dessas escolhas, nos ajuda a iluminar ideias, agentes e instituições nesse importante momento da história da preservação de bens materiais pelo Estado brasileiro.

Em 1987, o arquiteto pernambucano Geraldo Gomes da Silva escreve sobre a arquitetura eclética em Pernambuco, em um capítulo de livro organizado por Annateresa Fabris. Na curta apresentação do livro ${ }^{5}$, Fabris situa o lugar historiográfico desejado para essa publicação na revisão que faz sobre o ecletismo: fornecer um panorama articulado de um "fenômeno que transcendeu a arquitetura e as artes, para caracterizar a própria mentalidade duma época", em resposta à verificação de que a "questão eclética, por longo tempo esquecida pela historiografia artística", voltava nos anos 1980 a merecer o interesse dos estudiosos, "que sobre ela se debruçavam alheios aos preconceitos oriundos da ortodoxia da ideologia modernista".

Fabris referia-se à hoje já bastante conhecida e intricada relação entre a construção da memória nacional e a construção do presente, empreendida pelos "modernistas na repartição"6.

Geraldo Gomes da Silva, responsável por cobrir Pernambuco, ao abordar primeiramente o ecletismo no contexto europeu, conclui a favor da necessidade de uma historiografia mais "tolerante" com esse movimento:

(...) o que se constata é que a sociedade europeia no século XIX era muito mais complexa do que o fora alguns séculos atrás e já possuía uma herança cultural considerável à qual se juntava toda uma influência oriental. Acrescente-se a esse caldo de cultura os conflitos naturais advindos como o novo modo de produção industrial e pode-se esboçar um raciocínio mais tolerante, único caminho para entender a realidade daquela época? ${ }^{7}$.

Transcreve Claude Mignot, para afirmar, por meio de suas palavras, que "a coexistência dos diferentes estilos só é confusa para nós que não sabemos 
ler o seu código"8. Ainda no caminho da revisão historiográfica, Silva anota como Pevsner foi "cáustico em sua crítica"9 ao ecletismo e situa seu texto no tempo, a década de 1940, bem como no contexto de sua intricada relação com o ideário do Movimento Moderno.

Antes de concluir essa parte introdutória do ensaio com sua própria conceituação do ecletismo, Silva lança um recado aos historiadores do presente:

Desprezar toda a produção arquitetônica de mais de um século no continente europeu e, com menos intensidade, nos demais, é uma atitude pelo menos estranha, partindo de um historiador. Assim, o esforço maior a ser despendido deve ser no sentido de compreender o ecletismo, sem preconceitos sempre nocivos à pesquisa ${ }^{10}$.

Ao contextualizar, em seguida, a historiografia da arquitetura no Brasil, ressalta o papel dos "ideólogos da arquitetura moderna e também da arquitetura neocolonial", explicitando um dos principais pontos de contato dos dois grupos: "eram anti-ecléticos, embora por motivos distintos"11.

A análise de Silva segue, então, para o estudo do caso específico de Pernambuco. A igreja da Sé aparece como último exemplo do texto, depois de uma consideração final de ordem metodológica.

A igreja aparece como a possibilidade de "ilustrar a história da mudança do gosto artístico em Pernambuco" e dos "sacrifícios" a que um edifício teve de se submeter para "satisfazer a moda então vigente". Silva ilustra seu estudo com fotografias das diferentes épocas tratadas: a igreja no século XIX (Figura 1), assim como a passagem da igreja pela "roupagem neogótica" em obra ocorrida entre 1911 e 1920 (Figura 2), e depois neobarroca, a partir de 1930 (Figura 3). Traz fontes textuais para abordar as "reações" a essas mudanças, mostrando-se interessado, sobretudo, em explicitar o contexto de sua produção, os significados possíveis desses desejos de transformação. Termina com uma crítica ao restauro da Sé, que não teria buscado o entendimento de significados no tempo histórico:

De qualquer forma, essa nova feição [neobarroca] da igreja durou quarenta e três anos e já estava se incorporando à paisagem urbana de Olinda quando a Fundação do Patrimônio Histórico e Artístico de Pernambuco (FUNDARPE) e a Secretaria do Patrimônio Histórico e Artístico Nacional (SPHAN) decidiram restaurar a velha Sé. As obras duraram quase uma década (1974-1983) e resultaram na restauração do presumível aspecto do templo no século XVIII [Figura 4]. A proposta original do arquiteto era a de restaurar a Sé a partir da sua fotografia datada de fins do século passado [Figura 1]. [...]. Nenhum edifício do porte da Sé de Olinda, nem de sua importância para a nossa história, submeteu-se a tantas e tão radicais "cirurgias plásticas" e em tão pouco tempo. Não resta dúvida que essas transformações se fizeram ao sabor dos gostos contemporâneos. Procurar entender as circunstâncias em que floresceram e se desenvolveram esses gostos nos parece uma atitude mais correta do que a intolerância preconceituosa. Isto é válido para todos os fluxos culturais que determinam as feições das nossas habitações, o ecletismo inclúido, sem dúvida. A análise parcial da arquitetura, dissociando os seus autores dos seus usuários, induz a conclusões precipitadas e enganosas por ignorar o seu evidente conteúdo social, enquanto arte e expressão do modus vivendi da sociedade ${ }^{12}$.
8. Cf. Claude Mignot apud Geraldo Gomes da Silva (1987, p. 179).

9. Cf. Geraldo Gomes da Silva (1987, p. 179).

10. Cf. Geraldo Gomes da Silva (1987, p. 180).

11. Ibidem.

12. Cf. Geraldo Gomes da Silva (1987, p. 205). 
Figura 1 - Fotografia da Sé de Olinda no final do século XIX. Reprodução de Narciso, de imagem de autor desconhecido, pertencente à coleção do Padre Marcelo Carvalheira. Acervo Fundarpe, pasta 252. Publicada no livro Sé de Olinda, de José Luiz Mota Menezes, em 1985, e no artigo Arquitetura eclética em Pernambuco, de Geraldo Gomes da Silva, em 1987

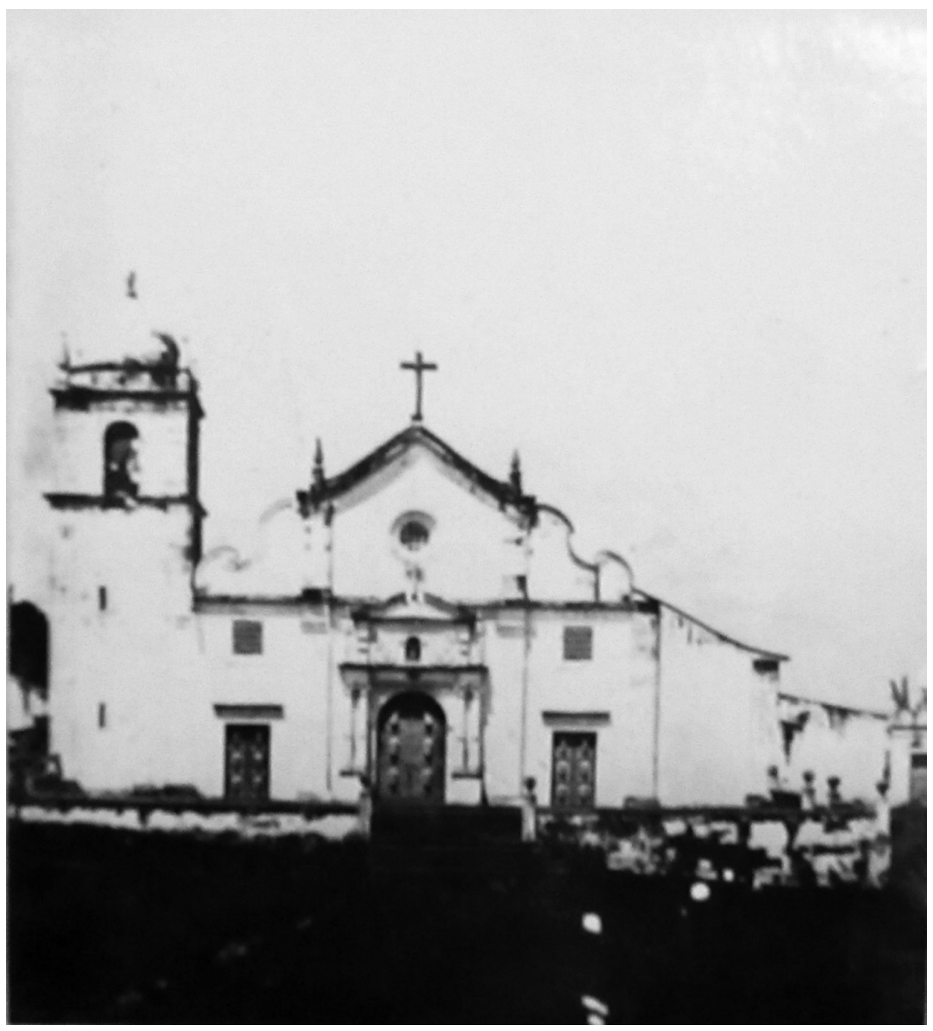

Figura 2 - Fotografia da Sé de Olinda com sua feição neogótica. Reprodução de 1975 de Narciso. Original de Benício W. Dias. Acervo Fundarpe, pasta 252. Publicada no livro Sé de Olinda, de José Luiz Mota Menezes, em 1985, e no artigo Arquitetura eclética em Pernambuco, de Geraldo Gomes da Silva, em 1987.

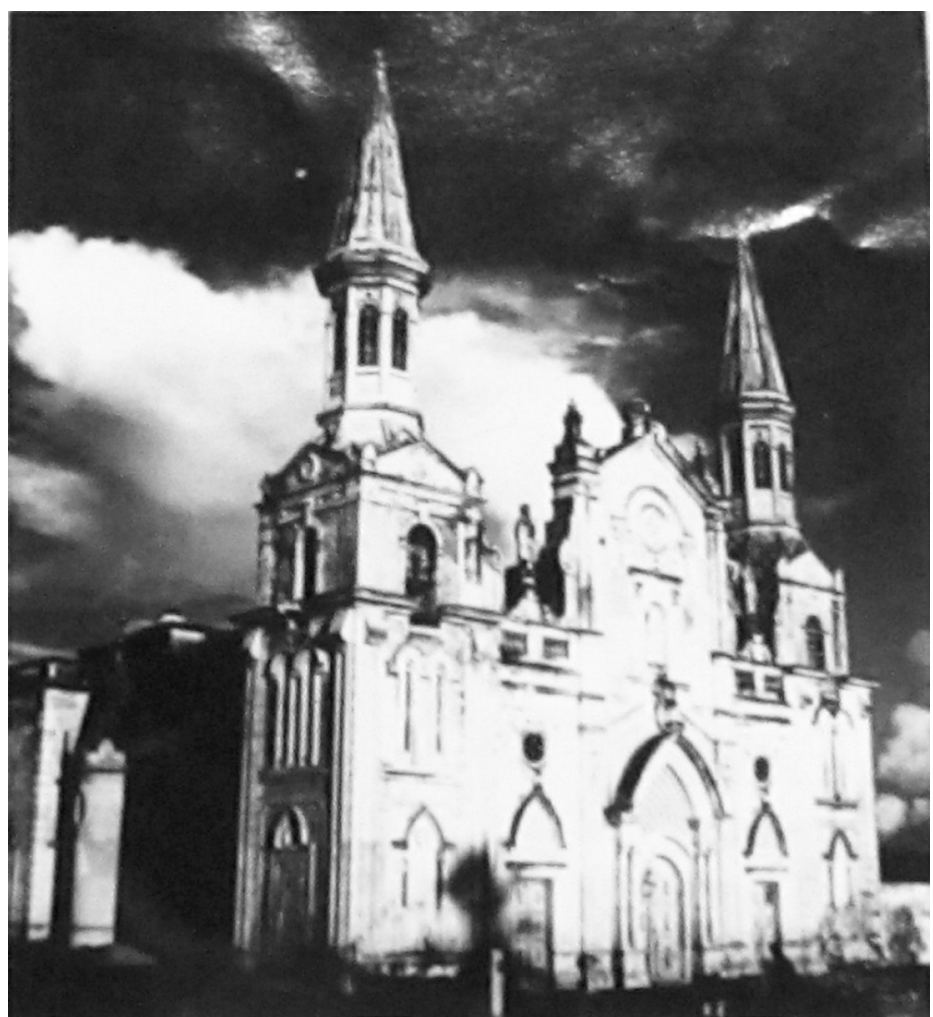




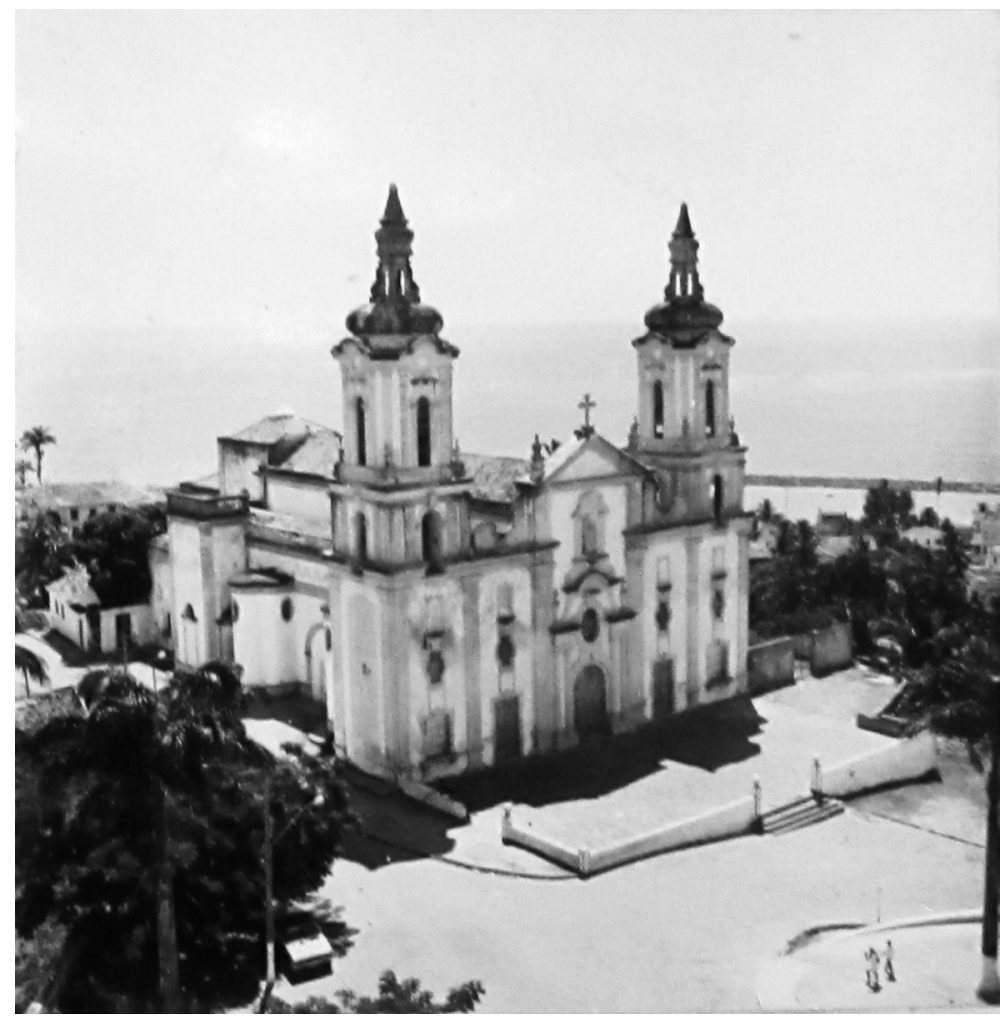

Figura 3 - Fotografia da Sé de Olinda com sua feição neobarroca. Fotografia de Narciso, de setembro 1973. Acervo Fundarpe, pasta 252. Publicada no artigo Arquitetura eclética em Pernambuco, de Geraldo Gomes da Silva, em 1987.

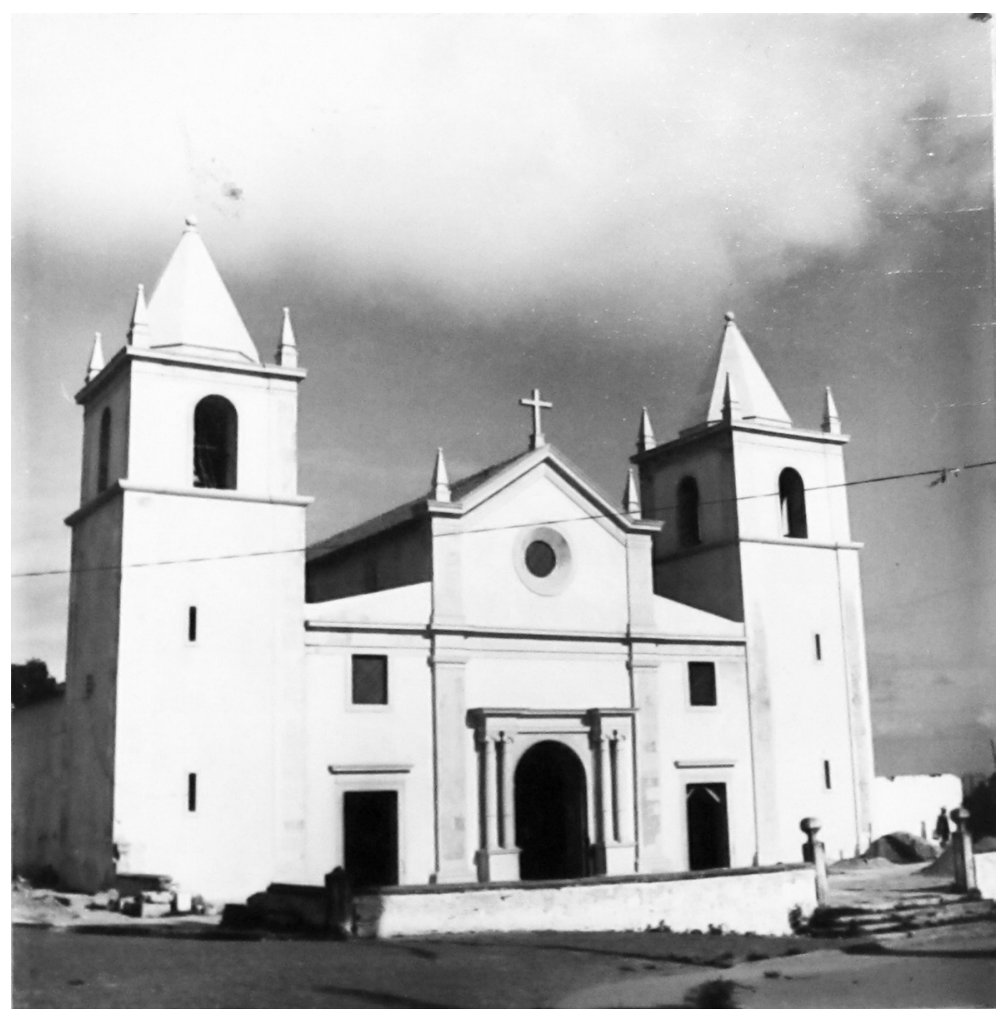

Figura 4 - Fotografia da Sé de Olinda, em 1976, com fachada restaurada. Fotografia de Narciso. Acervo Fundarpe, pasta 252. 
13. O documento publicado (1985) adicionou ao original (1969) um item sobre as obras de restauração, mantendo inalterado o restante do conteúdo.

14. Ver José Luiz Mota Menezes (2008, p. 45).

15. Ver José Luiz Mota Menezes (2008, p. 33).

16. Ver José Luiz Mota Menezes (1985, p. 67).

17. Menezes morou um ano em Portugal, com bolsa da fundação Calouste Gulbenkian, tendo escolhido o tema do Renascimento para seus estudos. Percorreu, na ocasião, mais de 50 igrejas com o partido arquitetônico da Sé, entendendo que ela tinha características típicas das basílicas do Renascimento. Informação obtida em entrevista concedida a Renata Cabral em 9 de setembro e 9 de outubro. $\bigcirc$ juízo de Silva sobre o restauro, expresso na ideia de "intolerância preconceituosa", é incisivo, como não o foi mais de uma década antes, quando ele era agente da própria história que relata, representando o lphan e dialogando em ofícios com a Fundarpe.

Um projeto "conjetural"

Um dos documentos-chave para entender o projeto inicial de restauração da igreja da Sé é a dissertação do projetista do restauro José Luiz Mota Menezes para concurso para assistente da Faculdade de Arquitetura da Universidade Federal de Pernambuco, defendida em 1970 (mimeografada em 1969) e publicada em 1985 pela Fundarpe ${ }^{13}$.

A motivação para a elaboração do estudo teria sido um contato do padre Marcelo Carvalheira, no ano de 1966, que, residindo junto à igreja, começou a retirar o revestimento de escaiola das colunas de sustentação das arcadas da nave central, descobrindo serem de pedra calcária. Teria, então, solicitado ao arquiteto um exame da edificação. Menezes passou a estudar como era a edificação antes das intervenções do século XX, estudo que resultaria na dissertação ${ }^{14}$. Esse trabalho acadêmico, realizado em 1969, contemplaria, ainda, um projeto de restauração, que Menezes classifica como sendo "conjetural" 15 anos depois (2008), porque não teria ainda elementos suficientes para a averiguação das hipóteses levantadas no estudo, só possível a partir da própria obra de restauro com suas prospecções.

Conforme Menezes, as hipóteses de base do restauro teriam partido da retirada de camadas de reboco que cobriam as cantarias do interior da edificação, além de uma medição dos alçados interior e exterior, de algumas sondagens para verificação de prováveis vestígios de paredes e alicerces, de remanescentes da antiga construção situados acima dos forros e telhados e de levantamento fotográfico. A isso se somaram outras informações iconográficas e textuais: descrições, fotografias antigas, gravuras, desenhos, pinturas ${ }^{16}$ e, por fim, um estudo de exemplificações de igrejas portuguesas cujo partido arquitetônico é aquele de três naves, como a Sél7.

Se para o interior, os indícios de um outro tempo da igreja apareciam na cantaria e nos vestígios acima dos forros, remetendo a um passado mais longínquo, para a fachada tomou-se como principal referência a fotografia de fins do século XIX referida por Silva, anterior à primeira remodelação da igreja, em que ela apresentava uma feição seiscentista (Figura 1).

Ao descrever o estado em que a igreja se encontrava no presente, percorrendo a nave central, as capelas laterais, as naves laterais, a capela-mor, o plano do piso, as portas da fachada, Menezes escreve em termos comparativos, salientando "danos", "destruições", "prejuízos", a partir de equivalências ou distanciamentos de um "traçado anterior", um "aspecto primitivo". Em relação à fachada, ressalta que é possível se "assustar" ao se comparar a fotografia anterior à reforma de 1911, já que o exterior estaria "irreconhecível". 
O tema da restauração na dissertação é bastante voltado aos estudos dos achados parciais in loco, das documentações encontradas naquele momento e dos modelos portugueses, elementos esses que são os geradores das hipóteses de restauro. É apenas na primeira e na segunda páginas do item dedicado ao assunto que há uma reflexão de cunho mais teórico, a partir de uma citação do trecho de um boletim produzido pela Direção-Geral dos Edifícios e Monumentos Nacionais de Portugal, onde o autor estagiou por um ano. $O$ documento data de maio de 1948 e é bastante crítico em relação à prática das reintegrações, com considerações bastante atualizadas quanto às instâncias do restauro e às escalas de interesse:

A arte de conservar os monumentos não podia deixar de se tornar bastante complexa. Conservar é o resultado de considerações da mais variada espécie: interesse histórico, arqueológico ou arquitectónico, pictural, simplesmente sentimental. Razões de ordem secundária também influem circunstâncias práticas ou económicas. Por vezes é tão importante o monumento em si como o quadro geral em que ele se situa - quantas vezes a paisagem é mais interessante que a obra do homem. Mas, as mais das vezes é o conjunto dos elementos arquitectónicos, paisagísticos, pinturescos, sentimentais que é preciso respeitar. Por isso, o cuidar dos monumentos não pode ser obra de um arqueólogo ferrenho, de um técnico despótico, de um pintor, nem mesmo de um poeta... O conservador de monumentos antigos há que participar de todas estas qualidades e a sua tarefa é cheia de subfilezas, só havendo para a complexidade problemas, soluções de compromisso.

Quem se atreveria hoje a despir a charola dos Templários em Tomar dos ouropéis que D. Manuel thes acrescentou? Quem teria a audácia de propor a substituição da capela-mor dos Jerónimos por obra nova, ainda que aparecesse agora o respectivo risco primitivo? A noção perigosa do reintegrar já causou grandes prejuízos artísticos, grandes danos à sensibilidade da gente. Admitamos que Viollet-le-Duc no seu tempo nutrisse uma ideia do restauro diferente da dos nossos dias; o que nunca the perdoaremos é que da sua concepção do restauro dos monumentos houvesse resultado tal baralha de verdade e artifício que nos destruiu para todo e sempre não poucas fontes de profunda emoção.

Artisticamente, os monumentos são joias engastadas na paisagem ou nos centros urbanos; documentalmente, são focos de interesse que guardam os arcanos da História. Menosprezar estes testemunhos do passado seria ter a noção mesquinha de que o presente é um momento desligado das épocas que nos antecederam, seria encarar com indiferença animalesca as gerações que atrás de nós hão de vir ${ }^{18}$.

Menezes lê esse trecho como uma espécie de mea culpa da DireçãoGeral dos Edifícios e Monumentos Nacionais de Portugal, identificando na história do órgão erros lamentáveis ligados a "reintegrações" 19 .

entendimento do autor de que havia conceitualmente um diálogo de sua proposta de restauro com o documento português acontece a partir da ideia de que não seria a finalidade "restaurar aquela igreja construída no século XVI, da maneira como a encontraram os holandeses". $\bigcirc$ autor diz se sentir satisfeito "se, pelo menos, conseguirmos restabelecer aquele aspecto que possuía o velho monumento nos fins do século XIX [aspecto seiscentista da imagem fotográfica], acrescentado de todas as coisas que o enriqueceram, o fizeram viver desde aquele tempo"20 (Figura 5).

A fala de Menezes parece ser indício de que o restauro da Sé de Olinda revela uma aquisição disciplinar importante por parte de seu projetista, a
18. Cf. José Luiz Mota Menezes (1985, p. 63-64).

19. Cf. José Luiz Mota Menezes (1985, p. 65).

20. Ibid. (p. 68). 
21. Ibid. (p. 32-33)

22. Ver interpretação cuidadosa do artigo $9^{\circ} \mathrm{da}$ Carta de Veneza em Kühl (2010, p. 312-313).

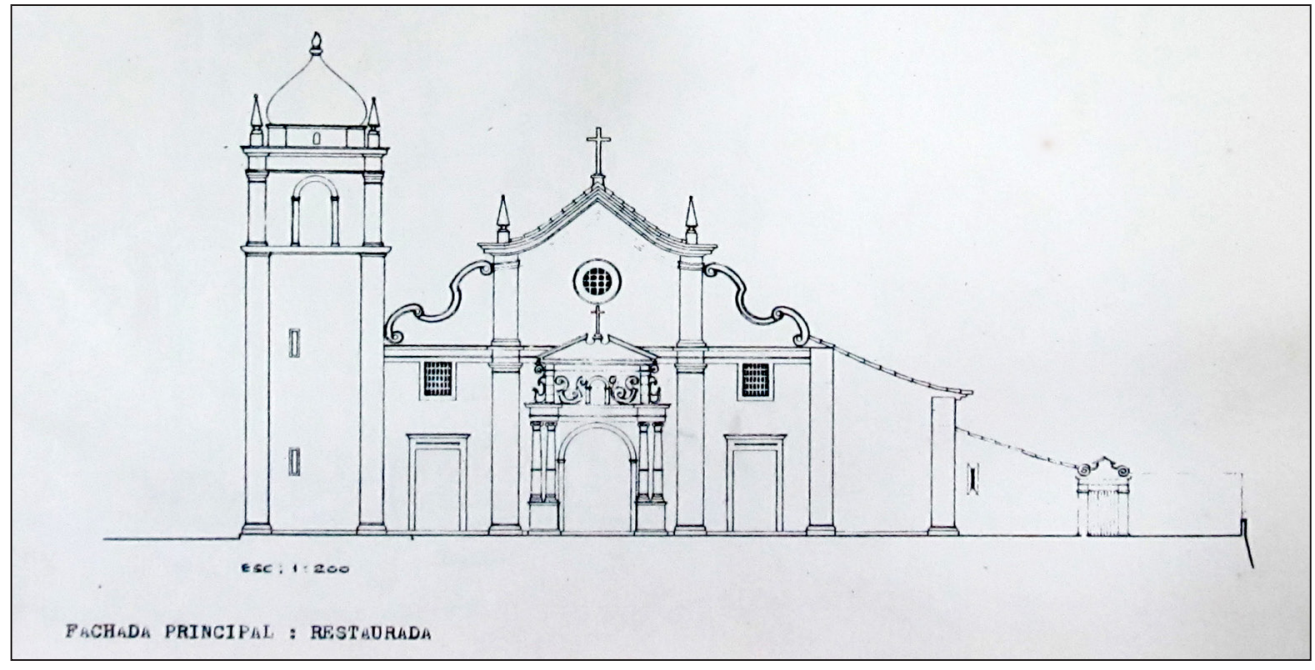

Figura 5 - Desenho da fachada principal da Sé de Olinda conforme proposta de restauro feita por José Luiz Mota Menezes na tese Sé de Olinda, para provimento do cargo de professor assistente da cadeira de História da Arte, na Faculdade de Arquitetura, da Universidade Federal de Pernambuco, em Recife, em 1969.

do interesse pelas transformações do edifício ao longo do tempo, para além do risco original, incluindo o período entre os séculos XVI e XIX; ademais, ilumina como esse entendimento era apenas parcial e tinha um aspecto muito seletivo no que diz respeito a que transformações poderiam ser consideradas como aceitáveis. Para ele 21 , "o ano de 1911 foi fatídico para a velha Catedral", quando ela adquiriu sua feição neogótica; depois de 1930, o que houve foi uma "nova mutilação", que transformou o templo em neobarroco. As "mutilações" caracterizam danos, supressão, diferentemente das "transformações", e é assim que essas intervenções foram vistas: como perdas de sua feição autêntica.

Para além das palavras, uma fonte iconográfica presente na tese de cátedra é marcante enquanto representação da distância entre o monumento tal como encontrado no tempo do restauro e o monumento desejado com a ação restauradora que o faria retornar ao seu perfil do século XIX: um desenho de Menezes em que sobrepõe as duas fachadas (Figura 6).

É importante anotar que o entendimento de que restaurar não é voltar a um estado anterior, presente no artigo $9^{\circ}$ da Carta de Veneza ${ }^{22}$, de 1964, não era uma aquisição conceitual presente de forma clara e consensual no Brasil naquele momento, nem particularmente no âmbito do $\mathrm{PCH}$ ou do Iphan.

Kühl, em artigo sobre a Carta de Veneza, ressalta que esse documento fazia parte da bibliografia utilizada por Hugues de Varine-Bohan no Curso de Conservação e Restauro realizado pela Faculdade de Arquitetura e Urbanismo da Universidade de São Paulo em parceria com o Iphan e o Condephaat e financiado pelo PCH em 1974. Segundo a autora, nas aulas de Augusto da Silva Telles, a Carta foi "extensa e fundamentadamente perscrutada". O arquiteto Fernando Machado Leal, que foi também professor nessa época e dizia seguir as 


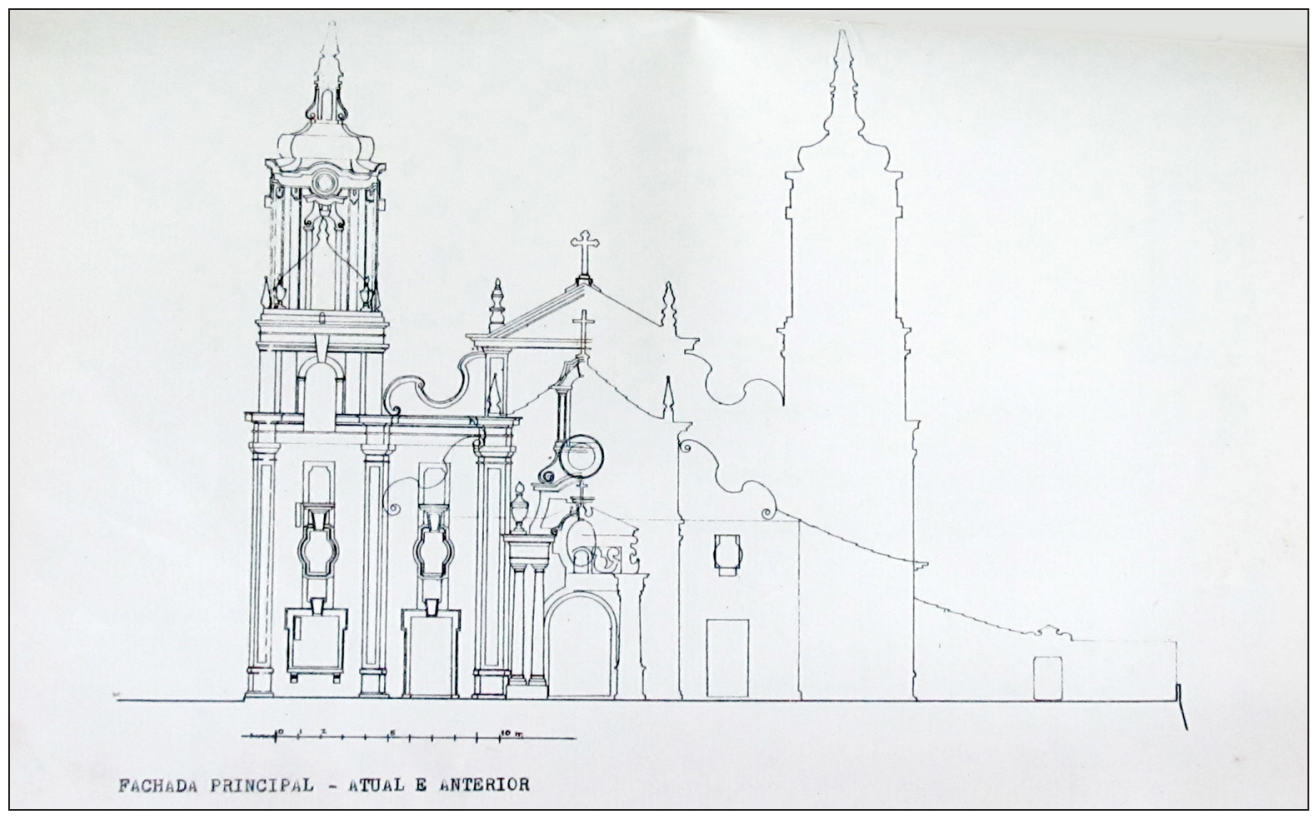

Figura 6 - Desenho sobrepondo o projeto de restauro da fachada da Sé de Olinda à fachada neobarroca existente à época, feito por José Luiz Mota Menezes para a tese Sé de Olinda, para provimento do cargo de professor assistente da cadeira de História da Arte, na Faculdade de Arquitetura, da Universidade Federal de Pernambuco, em Recife, em 1969

recomendações das Cartas de Atenas e de Veneza, definiria, segundo ela, a restauração como "fazer voltar a edificação à sua feição primitiva", em contradição com as definições da Carta ${ }^{23}$. Augusto da Silva Telles será o principal interlocutor do Iphan no caso do restauro da Sé, mas não foram encontrados registros de discussões conceituais a respeito do partido de restauro do edifício feitas por ele.

Em 2015, Menezes relata qual teria sido seu modo de pensar o restauro e a relação com o ecletismo naquele momento ${ }^{24}$. Ele se situa como interessado no edifício como resultado da "história da criação", ou, dito de outra forma, como artefato da história das ideias envolvidas nessa criação. Menezes declara que "tinha que entender a cabeça do outro", intervir "respeitando a obra do outro". Interessaria, ainda, dentro desse conceito, também mencionado por Menezes como "conceito de mentalidade", ver possíveis modelos referenciais para essas ideias e, por isso, a referência a igrejas portuguesas. Percebe-se que, nesse caso, há uma escolha primeira de ordem estética por parte do projetista, que valora a temporalidade seiscentista (documentada na foto da fachada) e quinhentista (na espacialidade do edifício) como sendo aquelas dignas de investigação a respeito das ideias, ou da "mentalidade". Quanto à valoração do ecletismo, Menezes assim depõe, agora já distanciado no tempo, sobre o entendimento da época:
23. Ver Beatriz Mugayar Kühl (, p. 297-98).

24. Entrevista concedida a Renata Cabral em 9 de setembro de 2015 .

não havia por parte do IPHAN, não havia por parte dos conceitos dos historiadores, valor com relação ao século XIX, porque era um século de estrangeiros. $\bigcirc$ ecletismo não tinha valor. $\bigcirc$ ecletismo era como se fosse, na realidade, uma coisa de fantasia burguesa [...]. Então, nesse 
25. Entrevista concedida a Renata Cabral em 9 de setembro de 2015 .

26. Restauração da Sé de Olinda - Museu, dossiê de José Luiz Mota Menezes e Fernando Borba (datilografado). $5^{\text {a }}$ SR IPHAN, Caixa PCH 141.

27. Idem.

28. Cf. José Luiz Mota Menezes (1985, p. 73).

29. Entrevista concedida a Renata Cabral em 9 de setembro de 2015 . aspecto, valorizou-se o colonial, o colonial foi o escolhido. E esse critério da escolha, nós aqui no caso de Pernambuco partimos para escolher a degradada Sé de Olinda $[\ldots]^{25}$.

Em dossiê preparado por Menezes e seu sócio Fernando Borba (não datado) ${ }^{26}$, referente às futuras obras de restauração e de adaptação da Sé, em que constam "todos os elementos técnicos necessários à abertura da licitação", fica clara a valoração positiva do colonial em detrimento do eclético. Em relação ao barroco, em item dedicado à "identificação" da igreja, explicita-se a "via crucis" que distancia aquele barroco autêntico do outro, de gosto eclético: "Em 1911, começa a 'via crucis' da velha Sé. Obras de 'remodelação' ao gosto eclético, ainda dominante em Pernambuco, a transformariam em neogótico, e depois em 1930, coroando a lástima, em neobarroca, não um barroco de caráter lusobrasileiro, mas uma formulação de teor germânico típico da Baviera"27.

É importante lembrar que, também na década de 1970, trava-se a conhecida polêmica entre Lucio Costa, já aposentado do Iphan, e Paulo Santos sobre o tombamento de nove edifícios ecléticos da Av. Rio Branco, no Rio de Janeiro, episódio que ajuda a mostrar como, ainda nesse momento, havia grande dificuldade em se reconhecer o valor estético do ecletismo.

Na dissertação de Menezes, há um parágrafo bastante esclarecedor de sua preferência arquitetônica, classificando a igreja como "a única igreja de caráter ainda renascentista-maneirista" no Brasil, quando ela era, na realidade, de características neobarrocas. A palavra "ainda", presente nessa sentença afirmativa do arquiteto, revela a importância da própria ação do restauro, uma ação ainda por se realizar, a trazer à luz a verdadeira Sé:

Desse modo, estão perfeitamente definidos todos os elementos necessários à possível reconstituição do monumento olindense, restando para a sua efetivação apenas meios econômicos que permitam enfrentar tal serviço. Naturalmente não nos cabe dizer do valor de tal empreendimento no contexto geral da Arquitetura tradicional brasileira, somente salientar ser a velha e tradicional Catedral de Olinda a única igreja, no Brasil, de caráter ainda renascentistamaneirista que utiliza um partido arquitetônico tão em voga no Portugal quinhentista ${ }^{28}$.

projeto apresentado ao Programa Integrado de Reconstrução das Cidades Históricas do Nordeste (PCH)

O projeto de restauro da Sé apresentado ao programa para apreciação foi, então, aquele da dissertação de Menezes (Figura 7). Em entrevistada concedida em 2015, ele relata esse fato como sendo de ordem puramente pragmática: "tinhase que apresentar alguma coisa. [...] Como eu tinha feito toda a dissertação e todas as plantas, as plantas foram apresentadas apenas raspando a etiqueta de nanquim $[\ldots]^{\prime \prime 29}$

A proposta, como visto anteriormente, era completamente calcada na referida fotografia do século XIX. Seria, dito de outra forma, uma transcrição, para o desenho, de uma imagem fotográfica de fachada (Figuras 1 e 5). É importante 


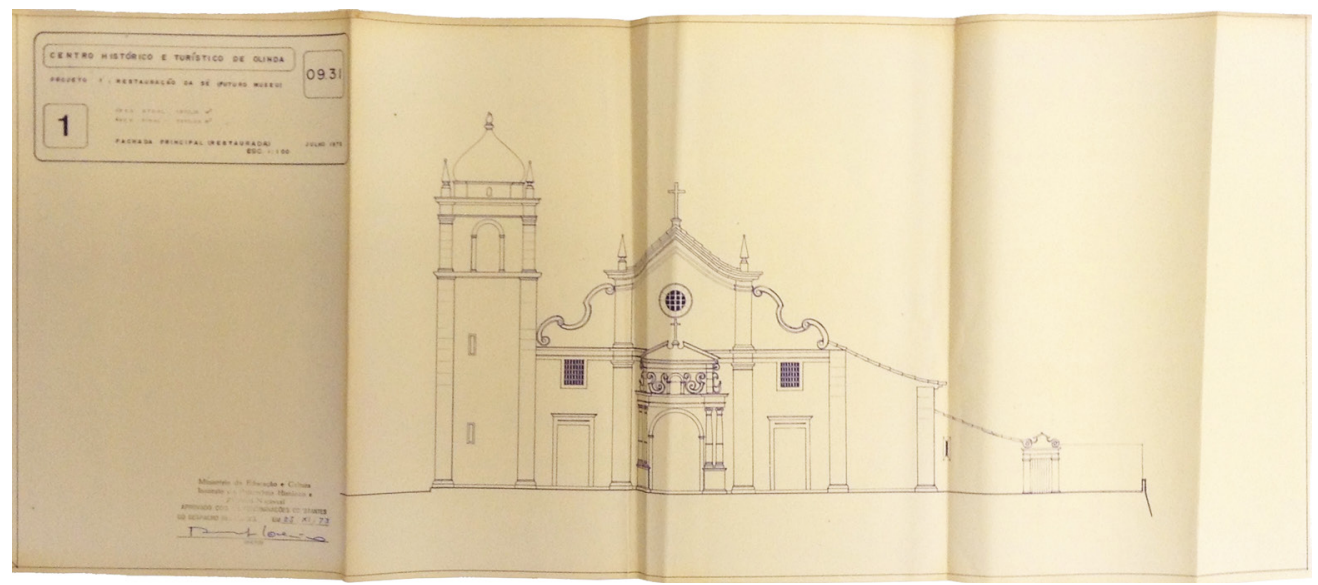

30. Informação $n^{\circ}$ 006/73. Assinado por Geraldo Gomes da Silva e datado de 7 de novembro de 1973 . Endereçado ao chefe do $1^{\circ}$ Distrito do IPHAN. $5^{\mathrm{a}} \mathrm{SR}$, Caixa PCH 142.

31. Informação $n^{\circ} \quad 006 / 73$. Assinado por Geraldo Gomes da Silva e datado de 7 de novembro de 1973. Endereçado ao chefe do $1^{\circ}$ Distrito do IPHAN. $5^{\mathrm{a}} \mathrm{SR}$, Caixa PCH 142.

32. Idem.

Figura 7 - Planta da proposta de restauro da fachada principal da Sé de Olinda, em 1973. Acervo da SEPLAN/PR, abrigado na 5a SR IPHAN, caixa PCH 141.

marcar, para as discussões que serão travadas adiante, que na fotografia e, portanto, no projeto, a igreja possuía apenas uma torre.

Será com base nessa proposta que o arquiteto Geraldo Gomes da Silva, convidado pelo então superintendente regional do Iphan, Ayrton Carvalho, analisará o projeto da Sé de Olinda, do Palácio dos Bispos de Olinda, da Capela da Divina Graça do Seminário de Olinda e da Casa de Detenção do Recife.

Em documento de novembro de 1973 - uma "análise final" do projeto de restauração da Sé -, Silva parte da premissa de que o restauro incorporará um retorno a características de um passado mais remoto e trabalha seu parecer, sobretudo, no sentido de problematizar o que deverá ser subtraído ou adicionado: "Na realidade, não se pode definir com clareza quais são as características formais originais do monumento. Estamos diante de um monumento que incorporou características de várias épocas, e o maior problema se constitui em eleger o que deverá ser subtraído ou adicionado"30.

Ele alerta para o comprometimento dos juízos, quando contaminados pelas escolhas estilísticas do presente:

Hoje analisamos os valores estéticos dos estilos de arquitetura do passado à luz de conceitos modernos e que não são os mesmos vigentes na época em que surgiram os citados estilos. Via de regra, a crítica da arquitetura atual considera o ecletismo como uma fase negra da nossa arquitetura, não somente nacional como também mundial ${ }^{31}$.

Silva elabora um diagnóstico que considera que o caso da Sé enquadrase nesse contexto da crítica de arquitetura da atualidade:

Sabemos que aqui não cabe discutir esse preconceito mas talves [sic] valha sublinhar que não era a arquitetura por si só que estava em crise. Ela era o reflexo de uma crise na sociedade responsável pelo seu surgimento.

A Sé de Olinda não foi poupada. Não era considerada monumento nacional e sofreu uma reforma neogótica em 1912, e outra neobarroca em 1930. $\bigcirc$ autor do projeto sugere a demolição de partes consideráveis das fachadas correspondentes a essas épocas ${ }^{32}$. 
33. Idem.

34. "Marin d'Olinda de Pernambuco/ T'Recif de Pernambvco", de autor desconhecido, cerca de 1630. Publicado em Joannes de Laet, Historie ofte Iaerlijck Verhael ... Leyden: Bonaventuere ende Abraham Elsevier, 1644.

35. Informação $n^{\circ} 006 / 73$. Assinado por Geraldo Gomes da Silva e datado de 7 de novembro de 1973. Endereçado ao chefe do $1^{\circ}$ Distrito do IPHAN. $5^{\mathrm{a}} \mathrm{SR}$, Caixa PCH 142.
Ele traz indícios, em seu discurso, de que a sugestão de demolição das partes neogóticas e neobarrocas possa revelar um "preconceito". Ao mesmo tempo, parece amenizar esse "preconceito" situando historicamente o ecletismo como um reflexo de uma "crise na sociedade" e usando a expressão "não foi poupada". A conservação das reformas ecléticas seria a defesa, então, de uma memória da crise?

Silva admite, no documento, logo em seguida, a opção de restauro proposta por Menezes, apenas sugerindo que haja a possibilidade de se mudar os rumos do projeto a partir das descobertas in loco: "Como o autor do projeto sugere o retorno do edifício à sua provável feição seiscentista, muitas de suas hipóteses somente poderão ser ratificadas após os serviços iniciais de remoção de revestimentos de paredes e pisos" ${ }^{\prime 3}$.

Aceita a opção de reconstituição a partir de uma determinada época, surgem dúvidas sobre a coerência entre as partes, como, por exemplo, sobre ser a época da cúpula da capela-mor a mesma da fachada seiscentista. Também, com a opção de retorno a uma feição não mais existente em sua integridade, as fontes tornam-se de fundamental importância. Nesse sentido, Silva questiona a fidelidade de gravura publicada em Joannes de Lae ${ }^{34}$, que serviu de base a algumas hipóteses levantadas por Menezes sobre a configuração da coberta da igreja antes do incêndio (Figura 8).

Silva conclui seu parecer fazendo referência à autoridade do estudo de Menezes e deixando, na ausência de uma crítica mais contundente e direta à anulação dos vestígios do passado recente, que as discussões relativas ao restauro fiquem no âmbito da melhor interpretação dos documentos e descobertas in loco:

Criticar é muito cômodo, como atitude. Porém, no presente caso, em que o projeto é resultante de uma tese de concurso para magistério na Faculdade de Arquitetura da Universidade Federal de Pernambuco, o exercício da crítica torna-se complexo, pois exige do analista um trabalho tão profundo quanto o do autor. Lemos a tese e tivemos acesso a uma boa parte dos documentos que servem de base no projeto, mas como o autor levanta hipóteses, achamos por bem emitir parecer sobre a viabilidade dessas suposições. Não pretendemos de maneira alguma obscurecer o brilho do trabalho apresentado, pelo contrário, nossa intenção é contribuir com uma parcela de interesse para que o resultado final seja tão bom quanto possível, hoje.

Mas, como dissemos anteriormente, este é um trabalho inicial. As obras de restauro, quando iniciadas, determinarão seu rumo mais sensato ${ }^{35}$.

Será justamente nessa passagem entre o projeto de Menezes presente na tese e as decisões tomadas a partir dos achados in loco, decisões compartilhadas com um colegiado, que o projeto de restauração da Sé se transformará bastante, a tal ponto que o desenho de fachada de Menezes torna-se irreconhecível na obra final (Figuras 7 e 4 ). 


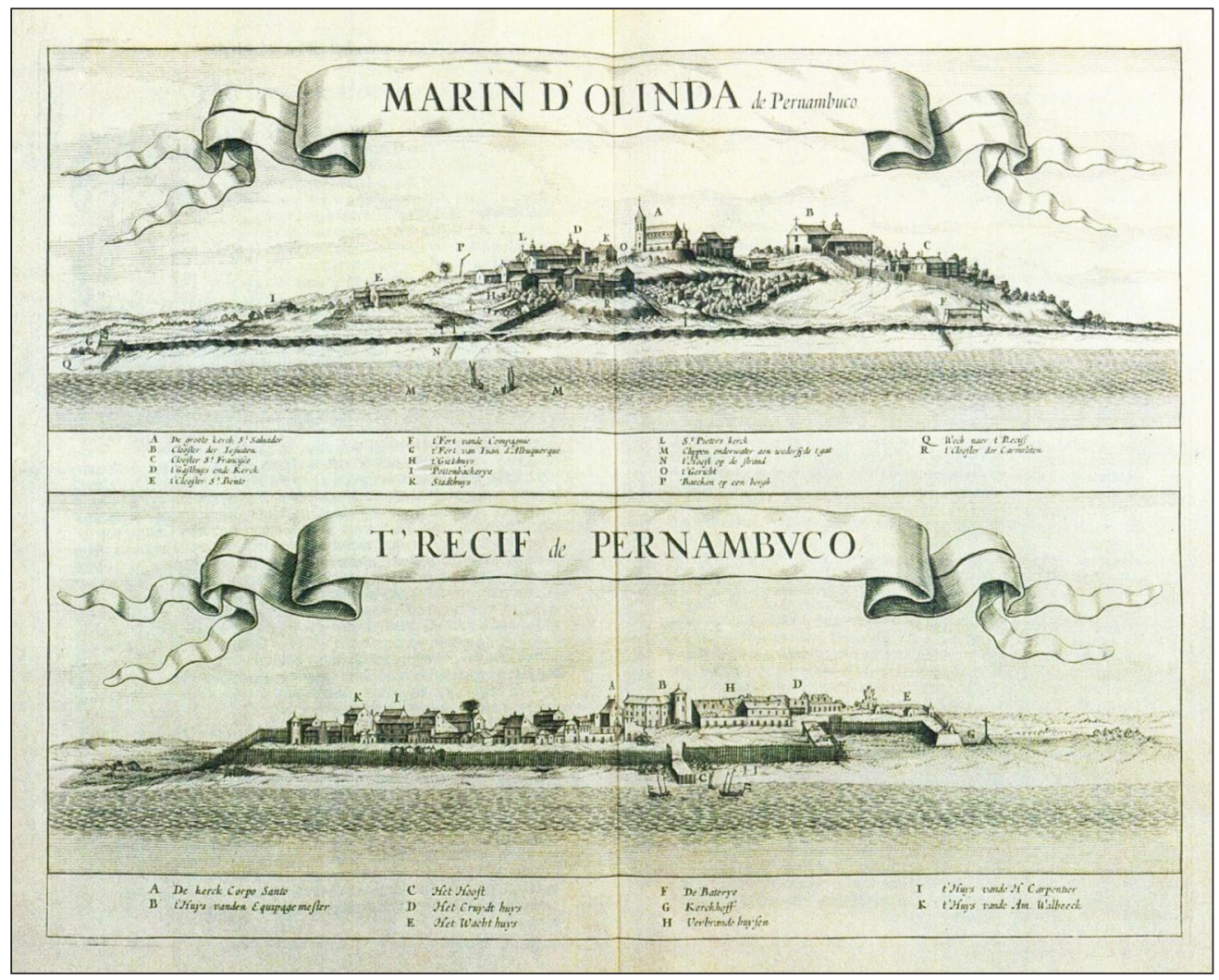

Figura 8 - "Marin d'Olinda de Pernambuco/ T'Recif de Pernambvco", de autor desconhecido, cerca de 1630. Publicado em Joannes de Laet, Historie ofte laerlijck Verhael ... Leyden: Bonaventuere ende Abraham Elsevier, 1644. Ver a lgreja da Sé ao centro da imagem Marin d'Olinda, indicada com a letra A. Disponível em: <htip://mww.mowic.org/images/Cartography\%20(2).jpg>, acesso em 05/12/2015.

A obra

A prática de restauro naquele momento incluía a compreensão, bem apontada por Jorge Tinoco ${ }^{36}$, que participou como funcionário da Fundarpe nas obras da Sé, de que se deveria "desnudar toda edificação, porque ela ia falar, ia dizer quem era". Era apenas a partir desse contato direto com a obra desnudada que se teriam as condições para o projeto de restauro deixar de ser "conjetural". Menezes refere-se a esse processo como o "strip-tease de um edifício"37. A retirada da alvenaria sobreposta à fachada anterior às reformas do século XX foi consequência desse processo $^{38}$ (Figura 9) que se soma à eliminação dos elementos aditivos da igreja neobarroca, como capelas laterais (Figura 10) e torres de concreto (Figura 11), e faz Tinoco rememorar esse momento como de "demolição massiva"39. Nesse sentido, se fôssemos continuar com a metáfora do strip-tease, poderíamos falar, para além da retirada da roupagem que estaria a esconder o corpo da obra, de uma ação mais contundente, a quebrar também os ossos desse corpo desnudo (Figura 12).
36. Entrevista concedida a Renata Cabral em 9 de outubro de 2015.

37. Entrevista concedida a Renata Cabral em 9 de setembro de 2015.

38. Sobre a fachada, segundo Menezes em entrevista citada acima, a "mutilação" teria sido superficial: "A fachada da Sé tinha uma camada de tijolo de cima a baixo cobrindo toda a fachada anterior, que foi muito mais barato para o arquiteto Rodolfo Lima, na primeira intervenção, e na segunda, para o alemão [...]. Era mais fácil, para eles, cobrir [...] do que você quebrar. Então a fachada estava lá atrás".

39. Entrevista concedida a Renata Cabral em 9 de outubro de 2015. 
Figura 9 - Fotografia da obra de restauro da Sé de Olinda, em janeiro de 1975, com "desnudamento" da fachada. Fotografia de Narciso. Acervo Fundarpe, pasta 252
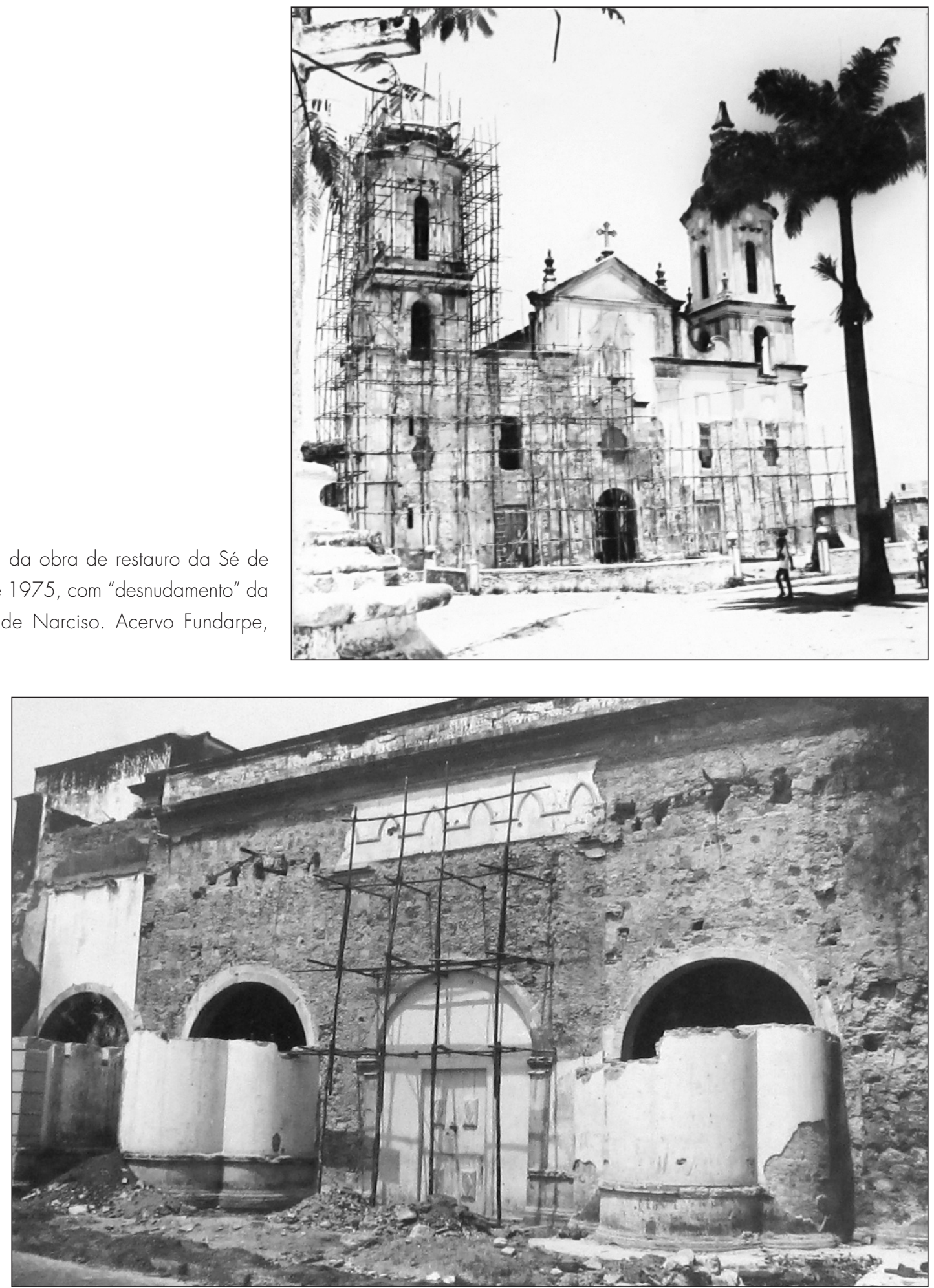

Figura 10 - Fotografia da obra de restauro da Sé de Olinda, em abril de 1974, com retirada das capelas laterais neobarrocas. Autoria não identificada. Acervo da SEPLAN/PR, abrigado na 5a SR IPHAN. BR - PE. 16 (013), pasta 4. 

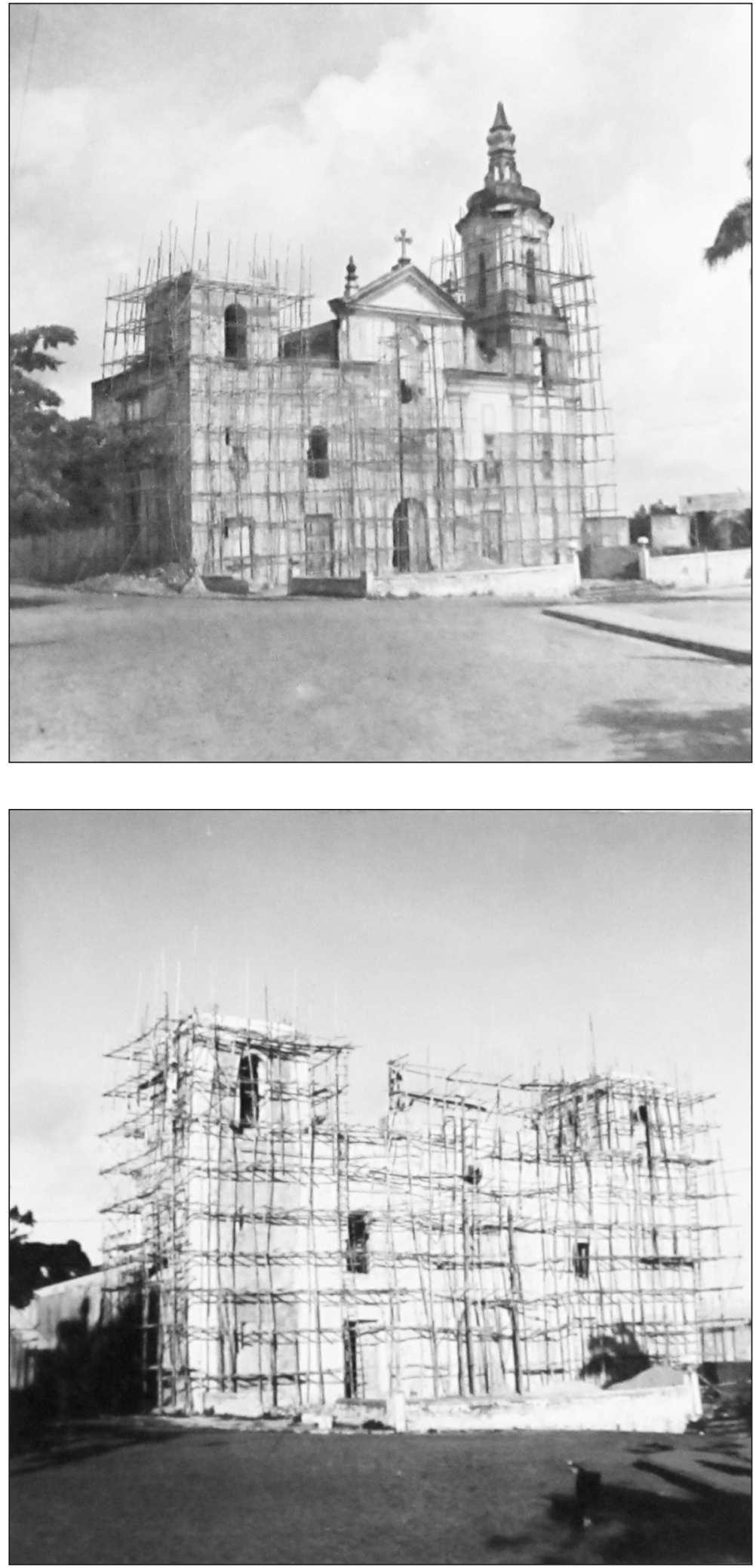

Figura 11 - Fotografia da obra de restauro da Sé de Olinda, em dezembro de 1974, mostrando uma das torres já destruída. Fotografia de Narciso. Acervo Fundarpe, pasta 252.

Figura 12 - Fotografia da obra de restauro da Sé de Olinda, em maio de 1975, mostrando as duas torres destruídas. Fotografia de Narciso. Acervo Fundarpe, pasta 252. 
40. Segundo Menezes (em entrevista concedida a Renata Cabral em 9 de outubro de 2015), a equipe era formada por Neide Fernandes, Jorge Tinoco, Jorge Passos e Carlos Alberto.

41. Entrevista concedida a Renata Cabral em 9 de outubro de 2015 .

42. Entrevista concedida a Renata Cabral em 9 de outubro de 2015 .

43. Cf. José Luiz Mota Menezes (1985, p. 79).

44. Ibid. (p. 76).

45. Cf. José Luiz Mota Menezes (1985, p. 76).
Foi nesse contato com os achados na obra que outras decisões foram tomadas pelos agentes envolvidos no processo. Além de Menezes, Fernando de Barros Borba e da equipe da Fundarpe ${ }^{40}$, havia ainda Ayrton Carvalho, mestre José Ferrão Castelo Branco e Marcelo Santos, do Iphan regional (Figura 13), e Augusto da Silva Telles e "Dr. Lúcio", como referido por Menezes, da direção-geral do Iphan.

Menezes tinha grande aproximação com Ayrton Carvalho, referindo-se a si mesmo como o "motorista do gordo" na labuta diária de estagiário voluntário no Iphan por aproximadamente dez anos ${ }^{41}$. A relação com Carvalho durante as obras do PCH continuaram, segundo ele, intensas, de tal forma que o Iphan e a Fundarpe seriam "entidades separadas sob o ponto de vista administrativo, mas unidas sob o ponto de vista de decisões" 42 .

As mudanças no projeto original entre a data de sua concepção e desenho e a obra final foram sinalizadas por Menezes em 1985: a construção da segunda torre, do lado do mar, o coroamento das torres com forma piramidal e a eliminação dos arremates barrocos e dos ornatos do pórtico. Segundo ele:

Em fotografia [Figura 14] foi desenhada a nova torre, mantendo-se, no entanto, todo o restante da fachada conforme projeto original, numa tentativa de manter a diretriz inicial. Paralelamente, no entanto, foi elaborada nova proposta para a fachada, pela Fundarpe, com a segunda torre e sem a conclusão do pórtico, no que se refere aos ornatos acima do seu entablamento, eliminando-se também os arremates barrocos e sugerindo-se coroamentos piramidais para as torres [Figura 15].

Tais sugestões foram levadas ao SPHAN e, em reunião no Rio de Janeiro, aprovou-se, após delongas, a última, a que foi executada. Abandonava-se assim a proposta original baseada na foto referida ${ }^{43}$.

No documento não está identificada a autoria individual das escolhas e decisões projetuais referentes aos aspectos acima referidos. Menezes compartilha tal responsabilidade com os agentes da Fundarpe e do Iphan:

À proporção que iam se revelando as descobertas dos vestígios da igreja seiscentista, ou anterior, em alguns trechos encobertos pelos rebocos, em reunião com técnicos da Fundarpe e do SPHAN, definiam as metas, ora mantidas do projeto original ou modificando aquela diretriz traçada e de responsabilidade do arquiteto. Daí em diante a sua responsabilidade não era integral, face a própria natureza do processo de uma restauração onde sua decisão não era a que sempre deveria prevalecer e sim a de um colegiado que analisava as prospecções, avaliava e decidia em conjunto ${ }^{44}$.

Há referência específica à participação da direção-geral do SPHAN nas escolhas, mas também sem a especificação dos nomes: "Outras vezes a decisão se desloca a instâncias superiores, no caso a direção geral do SPHAN, principalmente considerando o valor da Sé de Olinda perante a história da arquitetura no Brasil"45. 


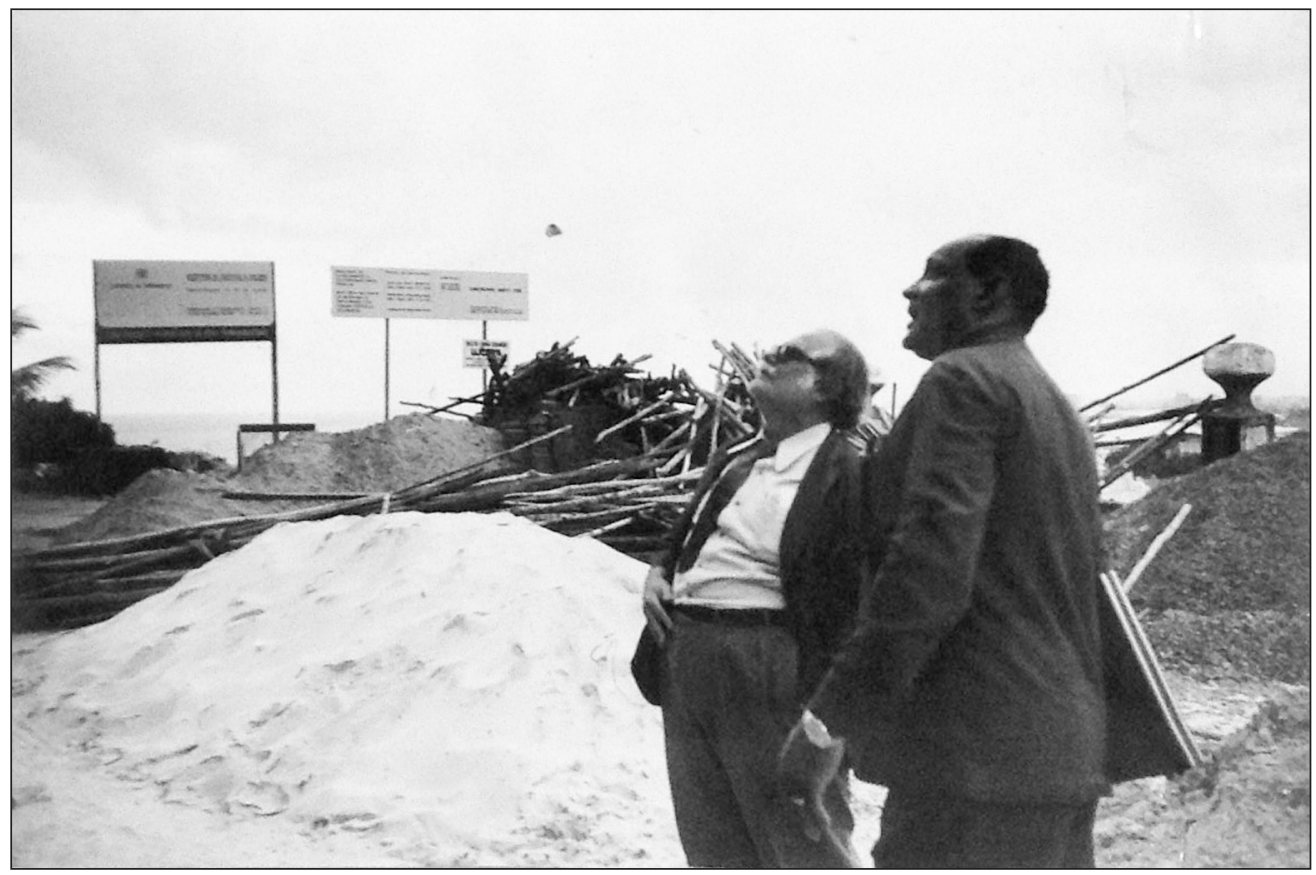

Figura 13 - Fotografia de Ayrton Carvalho e José Ferrão Castelo Branco em frente à obra de restauro da Sé de Olinda. Autoria e datação da fotografia não identificadas. Acervo da SEPLAN/PR, abrigado na 5 SR IPHAN, caixa PCH 142.

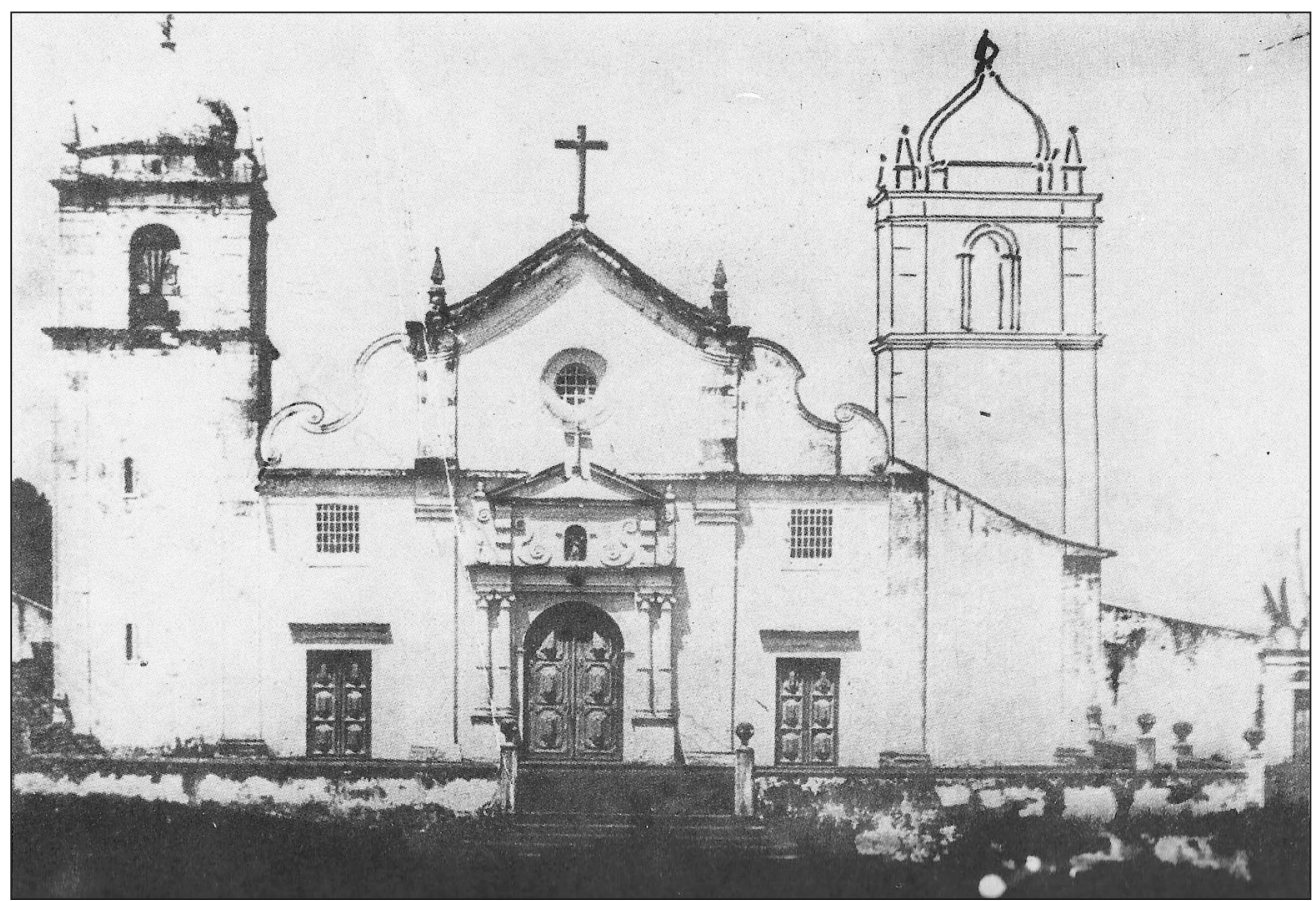

Figura 14 - Fotografia da Sé de Olinda, de autor desconhecido, com sobreposição de desenho representando a segunda torre da igreja. Publicada no livro Sé de Olinda, de José Luiz Mota Menezes, em 1985. 


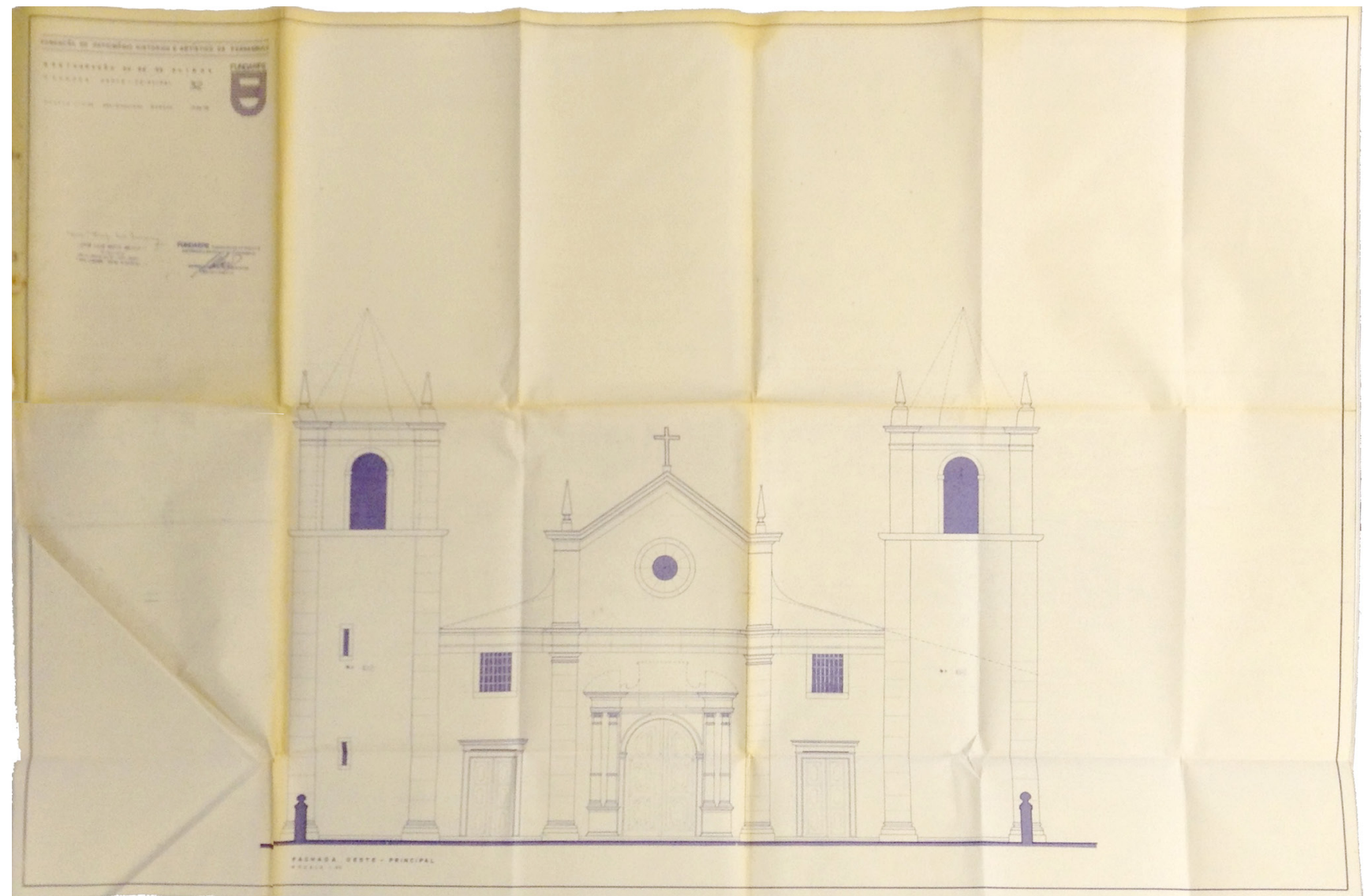

Figura 15 - Planta de fachada da Sé de Olinda, no projeto final, de 1975. Acervo da SEPLAN/PR, abrigado na 5a SR IPHAN, caixa PCH 141.

46. A eliminação dos arremates barrocos e dos ornatos do pórtico não parece ter sido alvo de opiniões divergentes e pautou-se pelo fato de não terem sido encontrados vestígios desses elementos na prospecção.

47. Menezes refere-se à derrubada das torres como uma decisão extremamente difícil e relata caso anedótico em que, perguntado sobre a responsabilidade dessa escolha e sobre o que faria na hipótese da falta de dinheiro para terminar o restauro, teria respondido "eu fujo", tamanho o impacto que causara a derrubada.

Entrevistas concedidas a Renata Cabral em 9 de
Em entrevista de 2015, Menezes é bem claro quanto à sua discordância em relação a duas tomadas de decisão referentes às torres da igreja ${ }^{46}$ : uma por parte de Lúcio Costa e a outra por parte de Ayrton Carvalho.

As duas torres neobarrocas existentes na igreja na ocasião do restauro eram de concreto e foram derrubadas ${ }^{47}$ para dar lugar a uma torre de coroamento bulboso. Ao final do processo, aparecem construídas na paisagem duas torres com coroamento piramidal. Em comum às propostas inicial e final, permeia o entendimento de que a unidade formal do bem restaurado é mais importante que sua historicidade, não havendo preocupação com a distinguibilidade das novas inserções.

Como registrado por Menezes já em 1985, em meio às obras de restauro, chega uma nova informação sobre as torres, vinda da pesquisadora Virgínia Pernambucano de Mello: em documento de 1669, diferentemente do que mostrava a fotografia do século XIX, havia referência à existência de duas torres que seriam anteriores à data do documento ${ }^{48}$.

Diante dessa informação, somada a uma reclamação do Porto do Recife sobre a retirada da torre do lado do mar, por ser um referencial de navegação, 
Lúcio Costa teria decidido construir a segunda torre igual à primeira. Menezes rememora que:

[...] Naquela altura, Virgínia Pernambucano, que era uma historiadora, localiza nos arquivos da Universidade a informação de que teria havido duas torres e a torre do lado do flanco tinha caído, desmoronado e nunca foi reconstituída. E eu tinha constatado as bases fortes dessa torre. Então o que se fez? Mandei uma planta para o dr. Lúcio Costa com as duas torres, dizendo, olha, essa segunda torre era uma torre que existiv e caiu. E dr. Lúcio disse "é melhor a gente errar a mais do que a menos" [...] no que eu fui absolutamente contrário com toda a segurança. Eu fui contrário ao meu amigo dr. Lúcio, achando que, se eu tinha uma fotografia da Sé com a torre caída, eu deveria deixar a torre caída ${ }^{49}$.

A segunda discordância teria ocorrido com Dr. Ayrton Carvalho, sobre a forma do coroamento das torres. $\bigcirc$ olhar de Menezes voltava-se para a torre do lado da rua, documentada na fotografia do século XIX, e o de Carvalho para a torre do lado do mar, desenhada na gravura publicada em Laet (Figura 8). Nenhuma presente, ao menos integralmente ${ }^{50}$, na temporalidade do restauro; ambas a serem reconstituídas pelas mãos dos restauradores. As diferenças significativas entre uma e outra seriam a datação, a forma arquitetônica e o tipo de fonte histórica de suporte para a informação. Na primeira, uma presença que tinha chegado mais longe no tempo, a forma bulbosa e a imagem de natureza fotográfica; na segunda, uma existência menos duradoura, a forma renascentista, piramidal, e a imagem de natureza pictórica, não detalhada, que seria complementada a partir da comparação com o coroamento da torre da lgreja de São João Batista dos Militares, do século XVI, também em Olinda ${ }^{51}$.

De um lado, estaria Menezes a falar sobre a primeira torre: "mas, professor, nós temos uma foto da torre bulbosa, quando ela caiv ela era piramidal, mas ela caiu. Ela caindo foi reconstituída da maneira do tempo" ${ }^{52}$. De outro, estaria Carvalho, rememorado por Menezes, a raciocinar a partir da torre voltada para o mar: "A de cá [do lado da rua], se eu restaurasse ela bulbosa, era verdadeira, do tempo da bulbosa. Mas se eu botasse do lado de cá [do mar] ela bulbosa, seria uma coisa estranha. Então vamos fazer piramidais as duas"53.

Menezes recorda que Ayrton Carvalho havia seguido seus passos em Portugal, indo às igrejas que ele havia visitado quando de seu estágio de um ano no país, e que, então, tinha verificado que a maioria das igrejas do século XVI tinha torre piramidal. Teria havido, nesse sentido, uma escolha de ordem formal, baseada, segundo Menezes, numa "coerência de tempo".

Jorge Tinoco pontua bem que, mais do que a iconografia histórica, a grande referência para a construção da torre piramidal foi o coroamento da torre da Igreja de São João ${ }^{54}$. Apesar de não ter participado do desenho da torre, Tinoco participou da obra e rememora que foi feito um ensaio com madeira e cordas baseado na lgreja de São João, para que, quando Silva Telles chegasse, pudesse visualizar a proposta no próprio local. Essa estrutura teria, então, servido como uma espécie de "gabarito" para a torre do lado da rua (Figura 16), não o sendo, contudo, para a do lado do mar, que terminou, pelas mãos do mestre que a executou, com uma proporção um pouco diferente, mais esbelta ${ }^{55}$. setembro e 9 de outubro de 2015.

48. Ver José Luiz Mota Menezes (1985, p. 78), no qual se transcreve trecho do documento, uma memória de João Gomes de Mello.

49. Entrevista concedida a Renata Cabral em 9 de setembro de 2015.

50. A torre neobarroca do lado esquerdo foi construída como um acréscimo à base existente. Ver José Luiz Mota Menezes (1985, p. 72), quando afirma: "A torre primitiva, a esquerda, apesar de mascarada com reboco e de ter recebido o acréscimo de concreto armado, do grande coroamento, é seguramente reconstituível".

51. Entrevista concedida a Renata Cabral em 9 de outubro de 2015: "Outra coisa que eu também discordei, mas perdi, é que Ayrton quis recompor a torre piramidal. Coroamento piramidal, como São João. Comparando São João à torre de Joannes de Laet. Como Joannes de Laet - o desenho - [...] como o desenho era muito exato [...] Ayrton então disse: a torre é piramidal".

52. Ibidem.

53. Ibidem.

54. Entrevista concedida a Renata Cabral em 9 de outubro de 2015.

55. Observa-se, na imagem publicada em Laet (Figura 8), uma forma não precisa em termos de conformação das arestas e, por outro lado, nota-se claramente a semelhança do coroamento das torres da Sé com a da Igreja de São João. 


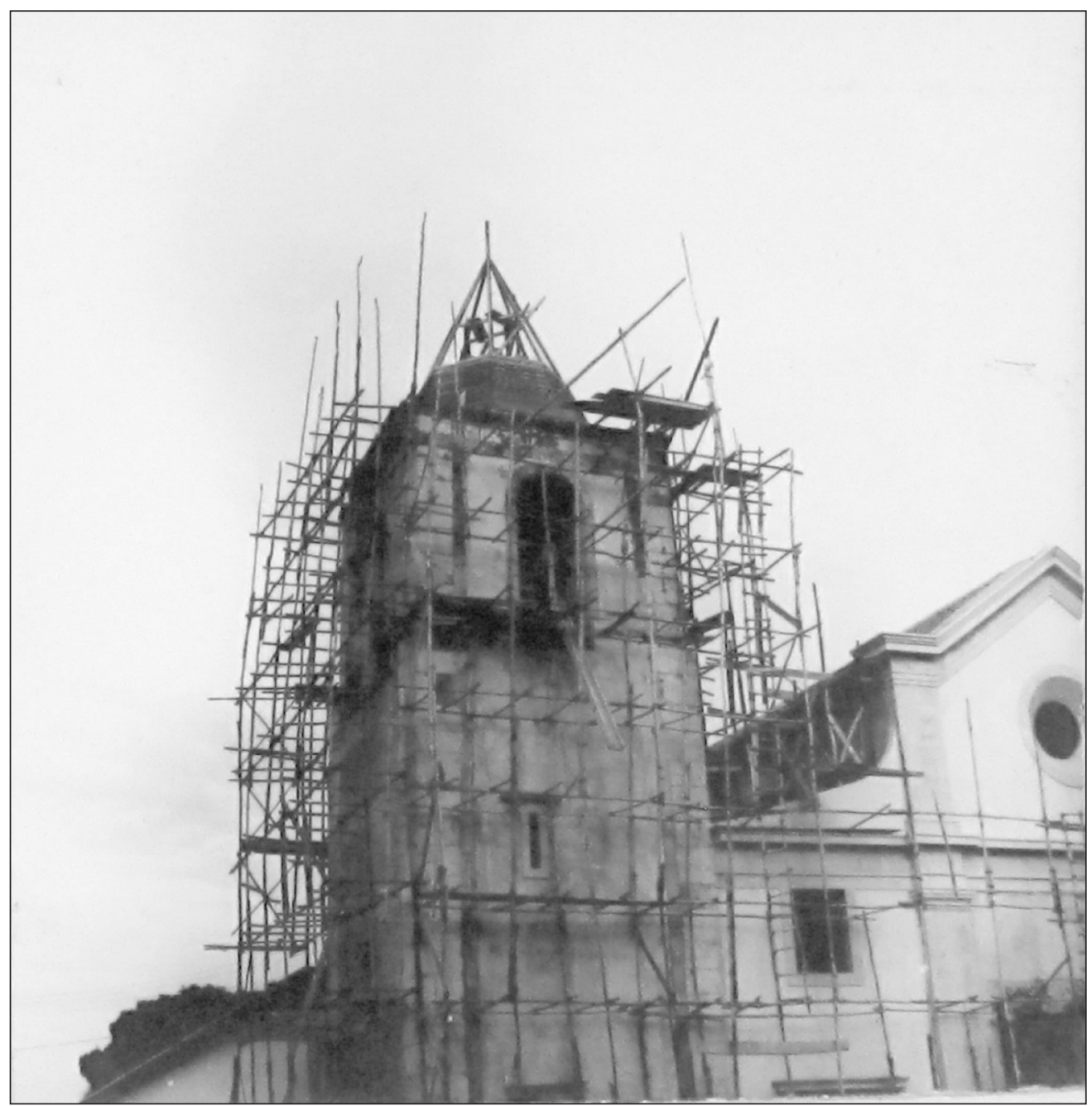

Figura 16 - Fotografia, de autoria de Narciso, da obra de restauro da Sé de Olinda, em março de 1976, mostrando "gabarito" para o coroamento piramidal da torre. Acervo Fundarpe, pasta 252.

Entre destruições, achados e invenção

No já mencionado livro de 2008 sobre a história da Fundarpe, escrito por Menezes por ocasião do 350 aniversário da instituição, a pedido do órgão, a corresponsabilidade das escolhas no caso da Sé é mais uma vez assinalada. Negam-se as acusações de "invenção" a partir do compromisso que teria havido com os "achados":

Em reuniões periódicas dos técnicos da Fundarpe, do IPHAN e da Seplan, as decisões eram tomadas segundo os elementos construtivos encontrados. Valeu o levantamento das características de cinquenta igrejas semelhantes existentes em Portugal e o relacionamento delas com a Sé de Olinda. Os que conheceram a Sé e viram o resultado, não acompanhando as obras, passaram a dizer que a edificação tornara-se uma invenção da Fundarpe e do IPHAN. Nada mais 
injusto. Na escolha do partido de intervenção, predominou aquele modelo de restauração em que se recompunham os elementos a partir dos achados, tudo conforme as decisões do grupo gestor da execução das obras - o arquiteto que havia realizado a primeira proposta era parte integrante apenas como vogal. A execução da intervenção era responsabilidade de um colegiado a quem se podem atribuir erros ou acertos. De toda a obra se conservou a documentação devida. $[\ldots]^{56}$.

Decisões colegiadas, como mostra este artigo, levaram, no processo de restauro da Sé, a uma progressiva simplificação formal de gosto renascentista, distanciando sua fachada, a cada passo decisório, da proposta inicial do arquiteto Menezes, que considerava a feição seiscentista na imagem da fotografia, com sua única torre bulbosa, simples volutas e ornatos do pórtico. Se as volutas e os ornatos do pórtico não foram reconstituídos por falta de "achados", as torres o foram, mesmo na ausência mais clara deles. Revela-se, assim, uma prática de restauro com uso das reconstituições a partir de analogias vindas de outros edifícios. Por isso, não se pode falar apenas em achados, mas, também, de invenções.

Não consta da pauta das discordâncias, no processo acima relatado, o valor das reformas ecléticas, consideradas como mutilações e não transformações. À época, Silva ensaiou algumas reflexões a respeito, mas sem a clareza e a contundência expressas anos depois em artigo de cunho acadêmico.

Não foram encontradas referências nos documentos consultados à proximidade da igreja da Sé com a caixa d'água modernista do arquiteto Luís Nunes, mas essa vizinhança bem representa, a partir de dois artefatos materiais, a ligação tão bem explorada pela historiografia, entre a Arquitetura Moderna, o Iphan e o ecletismo. Descontextualizando uma fala de Costa, poderíamos nos perguntar se a "boa arquitetura" da caixa d'água combinaria com a "falta de arquitetura" da Sé neobarroca ${ }^{57}$.

Percebe-se, no caso olindense, uma grande interação entre os agentes do Iphan local e da Fundarpe, ligados por laços profissionais e afetivos, como visto anteriormente sobre a relação de Menezes com Carvalho. Verifica-se, também, uma grande ingerência do Iphan central nos processos decisórios relativos ao projeto. Pesquisa mais ampla de arquivo precisaria ainda ser feita para esclarecer o papel de agentes como Silva Telles, sabidamente conhecedor das discussões teóricas internacionais.

Entre as reformas ecléticas do começo do século e o restauro da década de 1970, hoje é difícil dizer qual foi o mais destrutivo da feição precedente a cada um deles.

Quem hoje visita a Sé encontra um painel institucional de informe ao turista, que, para além de outras imprecisões, não faz referência ao restauro da década de 1970. Descreve apenas que "sua fachada é em estilo colonial renascentista e barroco. Possui três portas em madeira ladeadas por colunas jônicas, que formam com seu frontispício e suas torres um belo conjunto arquitetônico". A Sé restaurada, agora já com 32 anos, não é revelada, nas palavras da placa, em seu aspecto mais importante: enquanto documento autêntico da história da preservação no país.
56. Cf. José Luiz Mota Menezes (2008, p. 48).

57. Ver Costa apud Lia Motta (1987). 
58. Sobre a experiência do SPHAN em São Paulo no campo do restauro entre 1937 e 1975, ver Cristiane Souza Gonçalves (2007) e suas análises sobre a influência das recomendações internacionais nas posturas oficiais do órgão, com observações sobre a presença do conceito de "unidade estilística", ligado ao pensamento violletiano, na prática restauradora do órgão.

59. A exemplo de restauros atuais, em que se voltou a um estado precedente, ver Natália Miranda Vieira (2012 e 2014). $\bigcirc$ caso de Olinda, aqui tratado isoladamente, pode ser, em artigos futuros, investigado a partir de seu potencial representativo ou de singularidade dentro do universo de intervenções do PCH e do Iphan ${ }^{58}$.

Atualmente, temos clareza de como são historicamente datados os preconceitos para com o ecletismo, assim como o são as visões de restauro presentes no caso estudado. Cabe aos agentes do presente a percepção desse distanciamento, no sentido de evitar procedimentos equivalentes ${ }^{59}$. Afinal, hoje se sabe que os "achados" não são sujeitos com autoridade decisória, assim como as destruições e as "invenções" são de natureza exclusivamente humana.

\section{REFERÊNCIAS}

\section{FONTES TEXTUAIS}

Informação nº 006/73, IPHAN, $1^{\circ}$ Distrito. Assunto: Análise do projeto de restauração da Sé de Olinda apresentado pela Fundação do Patrimônio Histórico e Artístico de Pernambuco dentro do Programa Integrado de Reconstrução das Cidades Históricas do Nordeste. Assinado por Geraldo Gomes da Silva e datado de 7 de novembro de 1973. Endereçado ao chefe do $1^{\circ}$ Distrito do Iphan. Acervo SEPLAN/PR, abrigado na $5^{\text {a }}$ SR IPHAN, Recife, Caixa PCH 142.

MENEZES, José Luiz; BORBA, Fernando. Restauração da Sé de Olinda - Museu, dossiê datilografado. Acervo SEPLAN/PR, abrigado na 5ª SR Iphan, Recife, Caixa PCH 141.

MENEZES, José Luiz Mota. Sé de Olinda. Tese para provimento do cargo de professor assistente da cadeira de História da Arte, na Faculdade de Arquitetura, da Universidade Federal de Pernambuco. Recife, 1969. Acervo pessoal do arquiteto.

\section{ENTREVISTAS}

MENEZES, José Luiz Mota. Entrevista concedida a Renata Cabral, em 9 de setembro de 2015.

MENEZES, José Luiz Mota. Entrevista concedida a Renata Cabral, em 9 de outubro de 2015.

TINOCO, Jorge. Entrevista concedida a Renata Cabral, em 9 de outubro de 2015.

\section{LIVROS, ARTIGOS E TESES}

CAVALCANTI, Lauro. Modernistas na repartição. Rio de Janeiro: Editora UFRJ; MinC-Iphan, 2000 .

CORRÊA, Sandra Rafaela Magalhães. O Programa de Cidades Históricas (PCH): por uma política integrada de preservação do patrimônio cultural - 1973/1979. 2012. Dissertação (Mestrado em Arquitetura e Urbanismo) - Universidade de Brasília, Brasília, 2012. 
FABRIS, Annateresa (org.). O ecletismo na arquitetura brasileira. São Paulo: Edusp; Nobel, 1987.

FONSECA, Maria Cecília Londres. O patrimônio em processo: trajetória da política federal de preservação no Brasil. Rio de Janeiro: Editora UFRJ; MinC/Iphan, 1997.

GONÇALVES, Cristiane Souza. Restauração arquitetônica: a experiência do SPHAN em São Paulo, 1937-1975. São Paulo: Annablume/ Fapesp, 2007.

KÜHL, Beatriz Mugayar. Notas sobre a Carta de Veneza. Anais do Museu Paulista: História e Cultura Material, São Paulo, v. 18, n. 2, p. 287-320, jul.-dez. 2010.

MENEZES, José Luiz Mota. Sé de Olinda. Recife: FUNDARPE, 1985.

Ainda chegaremos lá. História da FUNDARPE. Recife: FUNDARPE, 2008.

MOTTA, Lia. A Sphan em Ouro Preto: uma história de conceitos e critérios. Revista do Patrimônio Histórico e Artístico Nacional, Rio de Janeiro, n. 22, p. 108-122, 1987.

PESSÔA, José (Org.). Lucio Costa: documentos de trabalho. Rio de Janeiro: Iphan, 1999.

RUBINO, Silvana. O mapa do Brasil passado. Revista do Patrimônio Histórico e Artístico Nacional, Brasília, n. 24, p. 97-105, 1996.

SANT'ANNA, Márcia. Da cidade-monumento à cidade-documento. A trajetória da norma de preservação de áreas urbanas no Brasil (1937-1990). Dissertação de Mestrado (Programa de Pós-graduação em Arquitetura e Urbanismo) - Universidade Federal da Bahia, Salvador, 1995.

SILVA, Geraldo Gomes da. Arquitetura eclética em Pernambuco. In: FABRIS, Annateresa (org.). O ecletismo na arquitetura brasileira. São Paulo: Edusp; Nobel, 1987, p. 177-207.

VIEIRA, Natália Miranda. Posturas intervencionistas contemporâneas e a prática brasileira institucionalizada. In: Encontro da Associação Nacional de Pesquisa e Pós-Graduação em Arquitetura e Urbanismo, 3, 2014, São Paulo. Anais do III Encontro da Associação Nacional de Pesquisa e Pós-graduação em Arquitetura e Urbanismo Arquitetura, Cidade e Projeto: uma Construção Coletiva. Campinas: Universidade Presbiteriana Mackenzie e Pontifícia Universidade Católica de Campinas, 2014.

VIEIRA, Natália Miranda; NASCIMENTO, José Clewton. A cristalização da "eterna imagem do passado" nas práticas preservacionistas dos sítios históricos brasileiros: perspectivas para a sua superação? In: Encontro da Associação Nacional de Pesquisa e Pós-graduação em Arquitetura e Urbanismo, 2, 2012, Natal. Anais do II ENANPARQ - Teorias e Práticas na Arquitetura e na Cidade Contemporâneas. Natal: Editora da UFRN, 2012.

\section{Artigo apresentado em 20/01/2016. Aprovado em 12/07/2016.}


